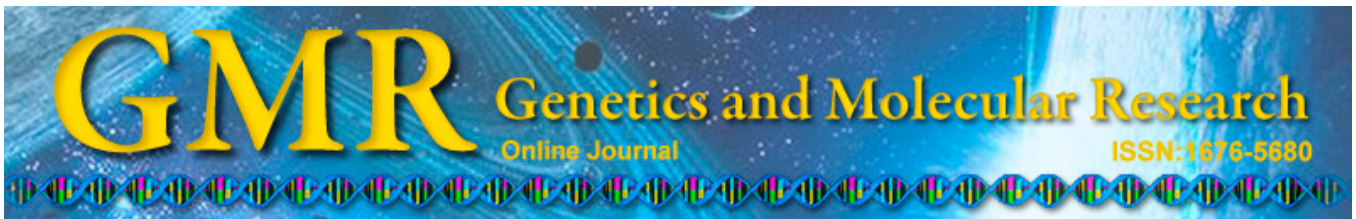

\title{
Polymorphic microsatellite loci for the razor clam, Sinonovacula constricta
}

\author{
H.-T. Ma ${ }^{1}$ H.-B. Jiang ${ }^{1}$, X.-Q. Liu ${ }^{1}$, X.-P. Wu ${ }^{1,2}$ and X.-M Wei ${ }^{1}$ \\ ${ }^{1}$ Shandong Provincial Key Laboratory of Restoration for Marine Ecology, \\ Shandong Marine Resource and Environment Research Institute, Yantai, China \\ ${ }^{2}$ College of Animal Science and Technology, Guangxi University, \\ Nanning, China \\ Corresponding author: X.-Q. Liu \\ E-mail: 1xq6808@163.com
}

Genet. Mol. Res. 14 (1): 145-148 (2015)

Received April 29, 2014

Accepted December 5, 2014

Published January 15, 2015

DOI http://dx.doi.org/10.4238/2015.January.15.17

\begin{abstract}
The razor clam, Sinonovacula constricta, is an important commercial bivalve and a popular mollusca food in China. Twelve polymorphic microsatellite markers were isolated from the razor clam using a partial genomic library enriched for tandem repeat sequences of $(\mathrm{CA})_{16},(\mathrm{GA})_{16}$. Polymorphisms of these loci were evaluated in a wild population of 30 individuals. The allele number of these polymorphic markers ranged from 5-15 per locus with an average of 9.333. Observed and expected heterozygosity values ranged from 0.192-1.000 and 0.219-0.906. Polymorphism information content ranged from 0.2090.892 with an average of 0.704 . Three loci significantly deviated from Hardy-Weinberg equilibrium after Bonferroni correction. No significant linkage disequilibrium was detected between these loci. This set of microsatellite loci are useful for genetic studies in $S$. constricta.
\end{abstract}

Key words: Microsatellites; Polymorphism; Sinonovacula constricta 


\section{INTRODUCTION}

The razor clam Sinonovacula constricta, a bivalve mollusk of the family Solenidae, is widely distributed in intertidal zones and estuarine water in China, Korea, and Japan. This bivalve is commercially important and a popular mollusca food in China. As 1 of the 4 major cultivated shellfish species in China, it has been cultured for more than 500 years in the Fujian and Zhejiang Provinces using natural resources (Feng et al., 2010). Recently, however, seasonal mortality, together with the decline of wild stocks, has affected this aquaculture industry. Therefore, resource management and stock improvement are important for the sustainable development from both industrial and scientific perspectives. Microsatellites or simple sequence repeats (SSRs) are tandemly repeated motifs of 1-6 bases found in all prokaryotic and eukaryotic genomes analyzed to date (Zane et al., 2002). In the field of fisheries and aquaculture, microsatellites are useful for the characterization of genetic stocks, broodstock selection, constructing dense linkage maps, mapping economically important quantitative traits, identifying genes responsible for these traits, and application in marker-assisted breeding programs (Chistiakov et al., 2006). Recently, 54 microsatellite markers in S. constricta were isolated and characterized (Niu et al., 2008a,b; Jiang et al., 2010; Liu et al., 2012); however, this was not sufficient for constructing linkage maps or trait improvement studies. The development of additional polymorphic markers for is urgently needed for the sustainable development of this industry. In this study, we developed and characterized 12 new polymorphic microsatellite loci for $S$. constricta, which will be useful in future studies.

\section{MATERIAL AND METHODS}

A microsatellite-enriched partial genomic library was constructed using total genomic DNA. This DNA was extracted from adductor muscle using the standard phenol-chloroform method (Sambrook and Russell, 2000). Genomic DNA was digested with the restriction enzyme Sau3AI (Promega, Madison, WI, USA) and ligated to a blunt-end adapter (OligoA: 5'GCG GTA CCC GGG AAG CTT GG-3'; OligoB: 5'-GAT CCC AAG CTT CCC GGG TAC CGC-3') with T4 DNA ligase (Promega). Ligated fragments were subsequently amplified by polymerase chain reaction (PCR) using OligoA as a primer before enrichment of microsatellite motifs. The reaction mixture $(20 \mu \mathrm{L})$ contained $0.5 \mathrm{U}$ Taq polymerase (Promega), 1X PCR buffer, $2.0 \mathrm{mM} \mathrm{MgCl}, 0.2 \mathrm{mM}$ of each dNTP, $0.2 \mu \mathrm{M}$ each primer, and approximate $20 \mathrm{ng}$ template DNA. The amplification reaction included 25 cycles at $94^{\circ} \mathrm{C}$ for $1 \mathrm{~min}, 60^{\circ} \mathrm{C}$ for $1 \mathrm{~min}$, and $72^{\circ} \mathrm{C}$ for $2 \mathrm{~min}$. Microsatellite loci were isolated using an enrichment procedure described by Carleton et al. (2002) using streptavidin magnetic beads (Dynal). Amplified fragments were denatured and hybridized to a combination of biotinylated probes (CA) $)_{16}$ GCTTGA-biotin and (GA) ${ }_{16}$ GCTTGA-biotin in $6 \mathrm{X}$ saline sodium citrate buffer containing $0.1 \%$ sodium dodecyl sulfate at $58^{\circ} \mathrm{C}$ for $1 \mathrm{~h}$. DNA hybridized to the probes was then captured by streptavidin magnetic beads (Dynal) and washed. The enriched DNA was amplified by post-hybridization PCR using OligoA and the same cycling program as was used for pre-hybridization-PCR. Next, the DNA was ligated into the pGEM-T easy vector (Promega) and transformed into competent cell JM109 cells (Promega). Positive clones were identified by PCR using SP6, T7 primers and $(\mathrm{CA})_{12}$ for CA-repeat or (GA) ${ }_{12}$ for GA-repeat. Positive clones, which contained fragments ranging from $400-900$ base pairs, were commercially sequenced.

Positive clones were sequenced using M13 primers in one direction using ABI 3730 XL (Applied Biosystems, Foster City, CA, USA). A total of 95 sequences contained microsatel- 
lites, and 43 pairs of primers were designed using the Primer Premier 5.0 program (Premier Biosoft, Palo Alto, CA, USA). Primer pairs were amplified in $10 \mu \mathrm{L}$ reactions containing $0.25-0.5 \mathrm{U}$ Taq polymerase (Tiangen, Beijing, China), 1X PCR buffer, 1.0-2.0 $\mathrm{mM} \mathrm{MgCl}_{2}, 0.2 \mathrm{mM}$ dNTPs, $0.2-1 \mu \mathrm{M}$ of each primer, and 20-100 ng total DNA. The PCR conditions were as follows: initial denaturation at $95^{\circ} \mathrm{C}$ for $5 \mathrm{~min}$, followed by 30 cycles of $94^{\circ} \mathrm{C}$ for $30 \mathrm{~s}$, a primer-specific annealing temperature for $30 \mathrm{~s}$ and $72^{\circ} \mathrm{C}$ for $1 \mathrm{~min}$, with a final extension at $72^{\circ} \mathrm{C}$ for $10 \mathrm{~min}$.

The designed primers were evaluated with a sample of 30 individuals collected from Yantai of the Shandong province. PCR products were evaluated by electrophoresis on a $9 \%$ non-denaturing polyacrylamide gel and visualized by silver staining. Allele size was determined using the software Gel-Pro Analyzer 4.5. The number of alleles, observed an expected heterozygosities, P value of Hardy-Weinberg, and linkage disequilibria were estimated using Genepop (Raymond and Rousset, 1995).

\section{RESULTS AND DISCUSSION}

A total of 12 of 43 loci were cleanly amplified and shown to be polymorphic. The allele number of these polymorphic markers ranged from 5-15 per locus, with an average value of 9.333. Observed heterozygosity ranged from 0.192-1.000 and expected values ranged from 0.219-0.906. In addition, polymorphism information content ranged from 0.209-0.892, with an average value of 0.704 . Eleven loci showed medium or medium-high levels of polymorphism in terms of polymorphic information content $(>0.25)$. After Bonferroni's correction, 3 loci significantly deviated from Hardy-Weinberg equilibrium (Table 1). No significant linkage

\begin{tabular}{|c|c|c|c|c|c|c|c|c|c|}
\hline $\begin{array}{l}\text { Locus/ } \\
\text { Accession No. }\end{array}$ & Primer sequence $\left(5^{\prime}-3^{\prime}\right)$ & $\mathrm{TA}\left({ }^{\circ} \mathrm{C}\right)$ & ) Repeat motif & $\begin{array}{l}\text { Size range } \\
\quad(\mathrm{bp})\end{array}$ & e $A$ & $H_{\mathrm{o}}$ & $H_{\mathrm{E}}$ & PIC & $\begin{array}{l}\text { HWE } \\
\text { P value }\end{array}$ \\
\hline $\begin{array}{l}\text { SC1-10 } \\
\text { KF999909 }\end{array}$ & $\begin{array}{l}\text { F: GTGTCGCCTCTATGCTCA } \\
\text { R: CATCCCCACTCCAACTTTA }\end{array}$ & 50 & $(\mathrm{AC})_{29} \ldots(\mathrm{CA})_{10} \ldots(\mathrm{AC})_{17}$ & $174-218$ & 10 & 0.704 & 0.617 & 0.654 & 0.9294 \\
\hline $\begin{array}{l}\text { SC1-11 } \\
\text { KF999910 }\end{array}$ & $\begin{array}{l}\text { F: GTTTCTAAAATGTCGGAGGTGC } \\
\text { R: GGTCCAACACGAAGGGAAGTAT }\end{array}$ & 62 & $(\mathrm{GT})_{10} \ldots(\mathrm{GT})_{15} \ldots(\mathrm{GT})_{9}$ & $170-212$ & 12 & 1.000 & 0.905 & 0.892 & 1.0000 \\
\hline $\begin{array}{l}\text { SC2-5 } \\
\text { KF999911 }\end{array}$ & $\begin{array}{l}\text { F: GCTAATCAAACATCGCACCG } \\
\text { R: CGTTGTCACTATTTACTTTCTCCTG }\end{array}$ & 56 & $(\mathrm{AC})_{12}$ & $170-202$ & 10 & 0.862 & 0.806 & 0.798 & 0.9564 \\
\hline $\begin{array}{l}\text { SC2-6 } \\
\text { KF999912 }\end{array}$ & $\begin{array}{l}\text { F: GCATAAGCCCATCCTTGAACA } \\
\text { R: GGTAACGCCAGGGTTTTCC }\end{array}$ & 60 & $(\mathrm{GT})_{32}$ & $312-390$ & 10 & 0.296 & 0.761 & 0.762 & $0.0000 *$ \\
\hline $\begin{array}{l}\text { SC2-10 } \\
\text { KF999913 }\end{array}$ & $\begin{array}{l}\text { F: CTACCAGTGAAGCCGACA } \\
\text { R: ACTCCCACAACCAAACAG }\end{array}$ & 50 & $\begin{array}{l}(\mathrm{AC})_{10} \ldots(\mathrm{AC})_{6} \ldots(\mathrm{CA})_{6} \\
\ldots(\mathrm{AC})_{7} \ldots(\mathrm{AC})_{16}\end{array}$ & $224-278$ & 10 & 0.956 & 0.853 & 0.830 & 0.9639 \\
\hline $\begin{array}{l}\text { SC2-13 } \\
\text { KF999914 }\end{array}$ & $\begin{array}{l}\text { F: TGTGCGTCGGTGCGATGTTT } \\
\text { R: CGCCAGGGTTTTCCCAGTCA }\end{array}$ & 60 & $(\mathrm{TG})_{16}$ & $238-284$ & 6 & 0.192 & 0.764 & 0.766 & $0.0000 *$ \\
\hline $\begin{array}{l}\text { SC3-15 } \\
\text { KF999915 }\end{array}$ & $\begin{array}{l}\text { F: GTGTCATGCGGATACGTG } \\
\text { R: GCTACCATCTGTGGAGGG }\end{array}$ & 50 & $(\mathrm{GT})_{25}$ & $188-272$ & 5 & 0.250 & 0.320 & 0.809 & $0.0000 *$ \\
\hline $\begin{array}{l}\text { SC4-1 } \\
\text { KF999916 }\end{array}$ & $\begin{array}{l}\text { F: GCTAATTGGTTTCACGCTCT } \\
\text { R: TTGGTAGTAGTGGCTTCCCT }\end{array}$ & 60 & $\begin{array}{l}(\mathrm{AC})_{8} \ldots(\mathrm{CA})_{8} \\
\ldots(\mathrm{GC})_{6} \ldots(\mathrm{CA})_{8}\end{array}$ & $200-240$ & 10 & 0.966 & 0.833 & 0.889 & 0.3872 \\
\hline $\begin{array}{l}\text { SC4-3 } \\
\text { KF999917 }\end{array}$ & $\begin{array}{l}\text { F: TGCGATGTTTGATTAGCG } \\
\text { R: AAGTTGGTCGATGGCAAG }\end{array}$ & 60 & $(\mathrm{TG})_{13}$ & $250-350$ & 14 & 0.857 & 0.886 & 0.209 & 1.0000 \\
\hline $\begin{array}{l}\text { SC4-5 } \\
\text { KF999918 }\end{array}$ & $\begin{array}{l}\text { F: TTTCCCGCCTTCACTGTTC } \\
\text { R: ACGCTCTACCACCTGAGCTATT }\end{array}$ & 60 & $(\mathrm{AC})_{13} \ldots(\mathrm{AC})_{24}$ & 158-198 & 5 & 0.233 & 0.219 & 0.792 & 0.5481 \\
\hline $\begin{array}{l}\text { SC4-8 } \\
\text { KF999919 }\end{array}$ & $\begin{array}{l}\text { F: ACGTCATGATTTACTACATCT } \\
\text { R: CTAATTTATACACCTATACGC }\end{array}$ & 60 & $(\mathrm{TG})_{5} \ldots(\mathrm{GT})_{5}$ & $134-150$ & 15 & 0.862 & 0.906 & 0.382 & 0.1673 \\
\hline $\begin{array}{l}\text { SC4-16 } \\
\text { KF999920 }\end{array}$ & $\begin{array}{l}\text { F: GTCGGTGCGATGTTTGATTAG } \\
\text { R: ACCACTGGGGCTCATTAGAAG }\end{array}$ & 52 & $(\mathrm{TG})_{11}$ & $166-206$ & 5 & 0.967 & 0.733 & 0.668 & 0.9989 \\
\hline
\end{tabular}

$\mathrm{F}=$ forward primer; $\mathrm{R}=$ reverse primer; TA = annealing temperature; $A=$ No. of alleles; $H_{\mathrm{O}}=$ observed heterozygosity; $H_{\mathrm{E}}=$ expected heterozygosity; PIC $=$ Polymorphic information content; HWE $=$ Hardy-Weinberg equilibrium. $*$ Significant deviation from HWE $(\mathrm{P}<0.05)$ after Bonferroni's corretion. 
disequilibrium was detected between the comparisons of these loci. All of the microsatellite primers developed in this study will be useful for population genetics analysis, linkage mapping, and molecular breeding in S. constricta.

\section{ACKNOWLEDGMENTS}

Research supported by the Program of Agriculture Thoroughbred Project, Shandong Province to Dr. Xiangquan Liu, Shandong Provincial Natural Science Foundation, China (\#ZR2012CM037), and Taishan Scholars Station of Aquatic Animal Nutrition and Feed to Limin Zhang.

\section{REFERENCES}

Carleton KL, Streelman JT, Lee BY, Garnhart N, et al. (2002). Rapid isolation of CA microsatellites from the tilapia genome. Anim. Genet. 33: 140-144.

Chistiakov DA, Hellemans B and Volckaert FAM (2006). Microsatellites and their genomic distribution, evolution, function and applications: a review with special reference to fish genetics. Aquaculture 255: 1-29.

Feng BB, Dong LL, Niu DH, Meng SS, et al. (2010). Identification of immune genes of the Agamaki Clam (Sinonovacula constricta) by sequencing and bioinformatic analysis of ESTs. Mar. Biotechnol. (NY) 12: 282-291.

Jiang Q, Li Q, Yuan Y and Kong LF (2010). Development and characterization of 14 polymorphic microsatellite loci in the razor clam Sinonovacula Constricta. Conserv. Genet. Resour. 2: 81-83.

Liu B, Shao YQ, Teng SS, Cai XL, et al. (2012). Characterization, development and utilization of EST-derived microsatellites in Sinonovacula constricta. Oceanol. Limnol. Sin. 43: 132-137.

Niu DH, Li JL and Zheng RL (2008a). Isolation and sequence characterization of microsatellite DNA in razor clam (Sinonovacula constricta). J. Ocean Univ. Chin. 38: 733-738.

Niu DH, Li JL and Liu BD (2008b). Polymorphic microsatellite loci for population studies of the razor clam Sinonovacula constricta. Conserv. Genet. Resour. 9: 1393-1394.

Raymond M and Rousset F (1995). Genepop (version 1.2): population genetics software for exact tests and ecumenicism. J. Hered. 86: 248-249.

Sambrook JD and Russell W (2000). Molecular Cloning: A Laboratory Manual, 2nd edn. Cold Spring Harbor Laboratory Press, Cold Spring Harbor, New York.

Zane L, Bargelloni L and Patarnello T (2002). Strategies for microsatellite isolation: a review. Mol. Ecol. 11: 1-16. 